\title{
Resveratrol Attenuates Bleomycin-induced Genotoxicity, Pulmonary Fibrosis and DNA Damage in Balb/C Mice with Ehrlich Ascites Carcinoma
}

\author{
Resveratrol Erhlich Asit Karsinomalı Balb/C Farelerde Bleomisin \\ Kaynaklı Genotoksisite Akciğer Fibrozu ve DNA Hasarını Azaltır
}

İsmail KOYUNCU iD

Department of Biochemistry, Harran University School of Medicine, Şanlıurfa, Turkey

\section{ABSTRACT}

Objective: Oxidative stress plays an important role in the pathogenesis and genotoxicity of bleomycin (BLM)-induced lung fibrosis. The aim of this study was to investigate the protective effect of resveratrol (RES) on lung fibrosis, DNA damage, and genotoxicity associated with BLM in mice with Ehrlich ascites carcinoma (EAT).

Methods: A total of $60 \mathrm{BALB} / \mathrm{c}$ mice were randomly separated into 6 groups. With the exception of the sham group, mice were injected intraperitoneally (i.p.) with $3 \times 105$ live EAT cells, then after 24 hours, mice were administered with BLM only $(10 \mathrm{mg} /$ $\mathrm{kg}$, i.p.), RES only (50 mg/kg, i.p.), BLM (10 mg/kg, i.p.)+RES (25 mg/kg, i.p.), and BLM (10 mg/kg, i.p.)+RES (50 mg/kg, i.p.) for 6 days. By examining the oxidant parameters in serum and the lung tissue, such as DNA damage (the comet assay and 8-OHdG), malondialdehyde (MDA), myeloperoxidase (MPO), protein carbonyl (PC), hydroxyproline (HPR), total oxidant status (TOS), and oxidative stress index (OSI), and antioxidant parameters such as superoxide dismutase (SOD), total antioxidant status (TAS), and glutathione (GSH), an evaluation was made of the BLM-related pulmonary toxicity and genotoxicity and the potential role of RES in preventing damage.

Results: The results determined that RES reduced the MDA, PC, TOS, MPO OSI, HPR, and DNA damage levels, which showed an increase related to BLM $(\mathrm{p}<0.05)$ and increased GSH, TAS, and SOD activities $(\mathrm{p}<0.05)$. It has also been observed that RES inhibits the BLM-induced fibrosis in histological findings.

Conclusion: Our results show that fibrosis that formed as a result of lipid and protein oxidization and DNA damage caused by BLM in the lungs of EAT-carrying mice could be reduced with the application of RES. Therefore, RES could be considered as an adjuvant therapy to conventional treatment methods for pulmonary fibrosis and DNA damage of the lungs.

Keywords: Bleomycin, ehrlich ascites carcinoma, pulmonary fibrosis, resveratrol, DNA damage

\section{öz}

Amaç: Oksidatif stres, bleomisin (BLM) kaynaklı akciğer fibrozis patogenezi ve genotoksisitesinde önemli rol oynamaktadır. Bu çalışmanın amacı, resveratrolün (RES) Ehrlich asit karsinoması (EAT) taşıyan farelerde BLM'ye bağlı gelişen genotoksisite, akciğer fibrozisi ve DNA hasarı üzerindeki koruyucu etkisini araştırmaktır.

Yöntemler: Çalışmada 60 adet Balb/c fare rastgele altı gruba ayrıldı. Sham grubu hariç diğer gruplardaki farelere 3x105 canlı EAT hücreleri intraperitonal (ip) olarak enjekte edildikten 24 saat sonra, farelere altı gün boyunca; BLM $(10 \mathrm{mg} / \mathrm{kg}$, i.p) tek başına, RES (50 mg/kg, i.p) tek başına, BLM (10 mg/kg, i.p) +RES (25 mg/kg, i.p), BLM (10 mg/kg, i.p) +RES $(50 \mathrm{mg} / \mathrm{kg}$, i.p) uygulandı. Serum ve akciğer dokusunda BLM'ye bağlı olarak artan; DNA hasarı (comet assay ve 8-OHdG), malondialdehit (MDA), myeloperoksidaz (MPO), protein karbonil (PC), hidroksiprolin (HPR), total oksidant durum (TOS) ve oksidatif stress indeksi (OSI) gibi oksidant parametreler ile süperoksit dismutaz (SOD), total antioksidant durum (TAS) ve glutatyon $(\mathrm{GSH})$ gibi antioksidan paremetreleri incelenerek, resveratrolün BLM'ye bağlı olarak gelişen, pulmoner toksisite ve genotoksisitenin önlenmesindeki potansiyel rolü araştırıldı.

Bulgular: Çalışma sonucunda resveratrolün (RES); bleomisine (BLM) bağlı olarak artış gösteren MDA, PC, TOS, MPO OSI, HPR ve DNA hasar seviyesini azaltırken $(\mathrm{p}<0.05)$, GSH, TAS ve SOD gibi antioksidanların aktivitelerini artırmışı ır $(\mathrm{p}<0.05)$. Ayrıca histolojik bulgularda'da RES’in BLM kaynaklı fibrozisi engellediği tespit edilmiştir.

Sonuç: Bu sonuçlar EAT taşıyan farelerde BLM'nin akciğerde neden olduğu DNA hasarı, lipit ve protein oksidasyonu sonucu oluşan fibrozisin RES uygulamasıyla azaltılabileceği ve RES'in akciğerdeki DNA hasarına ve pulmoner fibrozisin konvansiyonel tedavi yöntemlerine destekleyici tedavi sağlayabileceğini göstermektedir.

Anahtar kelimeler: Bleomisin, ehrlich asit karsinoma, akciğer fibrozis, resveratrol, DNA hasarı

Cite this article as: Koyuncu I. Resveratrol Attenuates Bleomycin-Induced Genotoxicity, Pulmonary Fibrosis and DNA Damage in Balb/C Mice with Ehrlich Ascites Carcinoma. Bezmialem Science 2018; 6(4): 262-71. 


\section{Introduction}

Bleomycin (BLM) is a cytotoxic antibiotic obtained from the Streptomyces verticillus strain and is used as an anticancerogenic drug in many cancer types, such as some lymphoma types, germ cell tumors, and head and neck tumors $(1,2)$. However, when used in cancer treatment, just as with other chemotherapeutic drugs, there may be significant unwanted side effects. As the enzyme hydrolase, which inactivates BLM, is found at particularly low levels in the lung tissue compared to other tissues, widespread fibrosis in the lungs and interstitial pneumonia occur, the antioxidative capacity is reduced, and free radical production is increased, leading to DNA damage and pulmonary fibrosis (3-6) Therefore, in patients using BLM, the rate of damage developing in the lungs can vary from $3 \%-40 \%$, and $10 \%$ of patients have been reported to be at life-threatening risk $(7,8)$.

These findings indicate that oxidative stress plays an important role in the BLM toxicity. However, in several studies conducted on animal models, it has been shown that antioxidant substances such as molsidomine (9), quercetin (10), berberine (11), atorvastatin (5), $\mathrm{N}$-acetylcysteine (12), resveratrol (13), ginkgo biloba (14), melatonin (15), and dexpanthenol (16) have a protective effect of varying degrees on the BLMinduced pulmonary fibrosis and damage (17).

Resveratrol (trans-3, 4', 5-trihydroxystilbene; RES) is a phytoalexin obtained from various plant sources such as grape skins in particular, cornelian cherries, mulberries, strawberries, cranberries, and other fruits, and it is known to have strong antioxidative, anti-inflammatory, and chemotherapeutic properties $(18,19)$. The antioxidant mechanism of RES can be explained by the inhibiting effects on the complex chain of reactive oxygen species (ROS) formation, capturing superoxide radicals produced in the cell, and the inhibition of lipid peroxidation (malondialdehyde) induced by oxidative stress (19).

Recently, RES has been found to have protective and healing effects on some cardiovascular diseases and lipid metabolism modulation; furthermore, it was associated with an increase in the cellular nitric oxide levels, vascular endothelium protection, and the preventative effects of platelet aggregation $(18,20-23)$. Robust data produced by several studies have focused on the beneficial effects of resveratrol in the prevention of cancer and coronary heart diseases. However, there have been few studies that have tested its potential use as a therapeutic substance against genotoxicity in oxidative organs and peripheral blood mononuclear cell (PBMC) associated with the use of various drugs.

Previous studies have shown that RES is extremely effective in the prevention of BLM-related pulmonary fibrosis and the treatment of fibrosis $(24,25)$. However, to the best of our knowledge, there has been no evaluation in terms of whether it is effective in the prevention of pulmonary toxicity and whether it affects the level of DNA damage caused by BLM in the lymphocyte cells and pulmonary tissue in mice carrying Ehrlich ascites carcinoma (EAT).

In the majority of previous studies, BLM has been applied to healthy rats or mice to form an idiopathic pulmonary fibrosis model similar to that in humans. In the current study, a different model was applied for the first time, to the best of our knowledge. In contrast to previous studies, in the current study model, BLM was not used as an agent forming pulmonary damage, but it was used as an antineoplastic agent for treatment purposes in mice with cancer. Thus, the genotoxic effects shown in the PBMC and pulmonary tissue and the protective efficacy of RES on this toxicity were examined when BLM was used for treatment purposes in cancer patients. As the physiological environment of normal mice and mice with cancer show a great difference from each other, it was considered that the actual toxic effect of BLM and the actual protective effect of the antioxidant substance would be able to be better examined in this model.

\section{Methods}

\section{Materials}

Bleomycin (BLM) was obtained from Onko Medical Company (Bleocin-S $15 \mathrm{mg}$, İstanbul, Turkey). It was administered intraperitoneally (i.p.) at the dose of $10 \mathrm{mg} / \mathrm{kg}$ b.w. BLM was dissolved in normal saline $(0.9 \% \mathrm{NaCl})$. Before each administration, solutions were thoroughly vortexed to obtain homogenous suspension.

\section{Experimental Methods}

Female and male BALB/C mice ( $n=60)$, weighing between $25 \mathrm{~g}$ and $30 \mathrm{~g}$, were obtained from Bezmialem Vakif University (İstanbul, Turkey). The mice were kept in a place that was environmentally controlled at a constant temperature $\left(21 \pm 1^{\circ} \mathrm{C}\right)$ and humidity $(70 \pm 5 \%)$ with a 12 -hour light/dark period until experiments. The mice were accustomed to the above conditions for a week prior to the study procedure and had free access to standard laboratory feed and water ad libitum. This research was approved by the Ethics Review Committee for Ethics in Animal Experiments of the Bezmialem Vakif University and strictly followed standards for the Guide for the Care and Use of Laboratory Animals (Ethics Committee Decision Number: 2016/66).

Mice were randomly assigned to 6 equal groups $(n=10)$. All mice, except those from the sham group, were inoculated i.p. with $3 \times 10^{5}$ cells in $0.5 \mathrm{~mL}$ of Hank's balanced salt solution on Day 0 in accordance with the modified method by Özkol et al. (26). After 24 hours of inoculation, mice were exposed for 6 days as follows: 1) Sham group: mice were treated with 0.5 $\mathrm{ml}$ of normal saline daily i.p.; 2) EAT group: mice were injected with $0.5 \mathrm{ml}$ of normal saline i.p. daily; 3) BLM (alone) group: mice were injected with $10 \mathrm{mg} / \mathrm{kg}$ b.w. of BLM i.p. daily; 4) RES (alone) group: mice were injected with $50 \mathrm{mg} /$ $\mathrm{kg}$ b.w. of RES i.p. daily; 5) BLM+RES ${ }_{25}$ group: mice were 
treated with $10 \mathrm{mg} / \mathrm{kg}$ b.w. BLM and $25 \mathrm{mg} / \mathrm{kg}$ b.w. of RES i.p. daily; 6) $\mathrm{BLM}+\mathrm{RES}_{50}$ group: mice were treated with 10 $\mathrm{mg} / \mathrm{kg}$ b.w. of BLM and $50 \mathrm{mg} / \mathrm{kg}$ b.w. of RES i.p. daily.

\section{Blood collection and isolation of Mice PBMC}

After the experimental process (6 days), blood samples were collected from each group while the mice were under anesthesia. After the animals were sacrificed, blood samples were collected according to the cardio-puncture method, and they were put into blood collection tubes with (for PBMC isolation) and without heparin (for serum). By the difference of density gradient, the PBMC were isolated by a gradient medium (Hystopaque 1077). Cell viability was assessed by using the trypan blue dye exclusion technique. The ratio of vital cells was at least $90 \%$ before the comet assay.

\section{Preparation of lung tissue homogenates}

Lung tissues were rinsed with ice-cold phosphate buffered saline and kept at $-80^{\circ} \mathrm{C}$ until the analysis. To produce a $10 \%$ $(\mathrm{w} / \mathrm{v})$ homogenate, tissues were homogenized with ice-cold Tris-HCl buffer (0.15 M, pH 7.4) for 5 minutes by a manual homogenizer. Then the homogenate was centrifuged at $7.000 \times \mathrm{g}$ for $15 \mathrm{~min}$. The pellet was separated, and the clear supernatant was used for the analysis. All procedures were performed at $4^{\circ} \mathrm{C}$.

\section{Measurement of biochemical parameters}

The blood urea nitrogen (BUN), creatinine (CRE), alanine trans aminase (ALT), aspartate transaminase (AST), and lactate dehydrogenase (LDH) levels were evaluated by relying on an enzymatic technique carried out by an autoanalyzer (Cobas integra 800, Roche). The myeloperoxidase (MPO) activity of lung homogenates was tested by the method defined by Bradley et al. (27).

The hydroxyproline (HPR) level was assessed in lung homogenates with commercially available kits (Hangzhou Eastbiopharm Co., Ltd., China) using a microplate reader (Spectra max M5, USA), and the absorbance was read at $450 \mathrm{~nm}$. The HPR level was expressed as $\mu \mathrm{g} / \mathrm{mL}$.

The glutathione (GSH) level was assessed through the reaction with OPA $(1 \mathrm{mg} / \mathrm{mL}$ o-phthaldialdehyde in methanol) following the modified technique by Kandar et al. (28). GSH was used as a standard. GSH samples were assessed using a microplate reader (Spectra max M5, USA), with excitation at $345 \mathrm{~nm}$ and emission at $425 \mathrm{~nm}$. Results were expressed as $\mathrm{nmol} / \mathrm{mL}$ and $\mathrm{nmol} / \mathrm{g}$ in serum and in wet tissue, respectively.

The malondialdehyde (MDA) level in lung homogenates and serum were assessed following the technique defined by Ohkawa et al. (29). The enzyme-linked immunosorbent assay (ELISA) plates were read by a microplate reader (Spectra max M5) at $532 \mathrm{~nm}$. The results were obtained as $\mathrm{nmol} / \mathrm{mL}$ in serum and $\mathrm{nmol} / \mathrm{g}$ in wet tissue, respectively.

The protein carbonyl (PC) level was assessed by the Cayman's Protein Carbonyl Assay Kit as carbonyl content in the sam- ples. This kit is based on the principle that utilizes the 2,4-dinitrophenylhydrazine reaction to measure protein carbonyl content in homogenate (9). The amount of the protein hydrozone produced is quantified spectrophotometrically at an absorbance of $360 \mathrm{~nm}$ by a 96-well plate reader (M5; SpectraMax, Sunnyvale, California, USA). The carbonyl content was standardized to protein concentration. The protein content in the samples was measured by the method of Lowry et al. (30), with bovine serum albumin as the standard.

Superoxide dismutase (SOD) is a very significant antioxidant enzyme. The SOD activity was measured at $505 \mathrm{~nm}$ and $37^{\circ} \mathrm{C}$, and calculated utilizing the inhibition percentage of formazan formation method of McCord and Fridovich (31). Quantification of SOD was done by using Randox commercial kits (Randox Laboratories, Crumlin, UK). The protocol as described in the manufacturer instructions was followed.

Total oxidant status (TOS) and total antioxidant status (TAS) were detected in serum and tissue homogenates using commercially available kits (Rel Assay, Turkey) with an autoanalyzer (Cobas integra 800, Roche). TOS and TAS results were presented in $\mathrm{mmol} \mathrm{H}_{2} \mathrm{O}_{2}$ equivalent/L (32) and mmolTrolox equivalent/L, respectively (33). The TOS-to-TAS ratio revealed the oxidative stress index (OSI), which is used as an indicator of total oxidative stress (34).

\section{Comet Assay}

The alkaline single cell gel electrophorese analysis (comet assay) was used to study the potential preventive effects of the RES on the BLM-induced DNA damage in the PBMC genotoxicity in mice. The comet assay was performed according to Kocyigit et al. (35) as follows: approximately $2 \times 10^{4}$ cells were suspended in low-melting-point agarose (LMA) (75 $\mu \mathrm{l}$ of $1.0 \%$ ) and stratified onto semi-frozen slides previously covered with a slim stratum of normal-melting-point agarose (1.0\%). Another stratum of $0.5 \%$ LMA was put over the second layer. The cells were dissolved for 2 hours at $4{ }^{\circ} \mathrm{C}$ in a solution (100 mM EDTA, $2.5 \mathrm{M} \mathrm{NaCl}, 10 \%$ DMSO, $1 \%$ Triton X-100, 10mMTris, $\mathrm{pH}$ 10.0). Following dissolution, the slides were exposed to electrophoresis in buffers $(0.3$ $\mathrm{M} \mathrm{NaOH}, 1 \mathrm{mM}$ EDTA, $\mathrm{pH}$ 13.1) for $30 \mathrm{~min}$. Then, the slides were neutralized within a Tris buffer $(0.4 \mathrm{M}$ Tris- $\mathrm{HCl}$, $\mathrm{pH}$ 7.5). The slides were carefully dried at $25^{\circ} \mathrm{C}$ in an incubator and marked with ethidium bromide $(10 \mu \mathrm{g} / \mathrm{mL}$ in distilled water, $70 \mu \mathrm{l} /$ slide). The slides were screened by using fluorescence microscope (Leica DM 1000, Solms, Germany) imaging system. A hundred cells were randomly scored in each sample on a scale of $0-4$ based on fluorescence beyond the nucleus. The used scale scores were as follows: 0 , no tail; 1 , comet tail, half the width of the nucleus; 2 , comet tail equal to the width of the nucleus; 3 , comet tail longer than the nucleus; and 4, comet twice the width of the nucleus. Scoring cells in this way have been shown to be as accurate and precise as using computerized image analysis. 


\section{Measurement of 8-OHdG in Serum and Lung Tissue}

8-hydroxy-2'-deoxyguanosine (8-OHdG) is a very significant indicator of oxidant-induced DNA damage. Quantification 8-OHdG was done by the OxiSelect Oxidative DNA Damage ELISA Kit (Cell Biolabs, San Diego, CA). The protocol as described in the manufacturer instructions was followed.

\section{Histopathological Method}

The mice were decapitated, and pulmonary tissue samples were fixed in $10 \%$ buffered formalin. Then, to remove formaldehyde from the tissues, the samples were washed overnight in running water. Routine pathology tissue procedures were applied with the tissues passed through a graded series of alcohol $(50 \%, 75 \%, 96 \%, 100 \%)$ and xylol, then embedded in paraffin blocks. Slices of 4-micron thickness were cut from the blocks for examination under the light microscope. The first three slices and every tenth slice were taken with a Leica RM 2125 RT onto slides.

The slides were passed through a series of graded alcohol and xylol, then stained with hematoxylin and eosin (H\&E). All the samples were examined at a $\times 40-x 100$ magnification under a high-resolution light microscope (Olympus DP 73 camera, Olympus BX53-DIC microscope; Tokyo, Japan), and the findings were scored with a modified semi-quantitative grading system as used by Ashcroft et al. (36). The evaluations according to this system were Grade 0, normal lung; Grade 1, minimal or moderate increase in thickness of the alveolar or bronchus wall; Grade 2, increased fibrosis and small fibrous formations together with mild damage to the lung structure; Grade 3, severe structural distortion and large fibrous areas (honeycomb appearance in the lung); and Grade 4, total fibrosis.

\section{Statistical Analysis}

Data obtained from the study samples were presented as the mean and standard deviation of mean (SD) and were analyzed by the one-way analysis of variance. Tukey's post-hoc test using the Statistical Package for Social Sciences (SPSS) version 11.5 (SPSS Inc.; Chicago, IL, USA) was performed. Differences among the average values according to $\mathrm{p}<0.05$ were evaluated as statistically significant.

\section{Results}

Results for oxidant status are shown in Table 1. The MDA, PC, TOS, and OSI level are commonly used as an indicator for measuring free radicals induced by oxidants. A statistically significant $(\mathrm{p}<0.05)$ increase was detected for the MDA, PC, TOS and OSI levels in the lung and serum of mice administered with BLM when compared to the normal and EAT control groups. On the contrary, the administration of RES in a dose-dependent way demonstrated a significant $(\mathrm{p}<0.05)$ decrease in the MDA, PC, TOS and OSI level in the lung and the serum when compared to the BLM group (Table 1).

The resveratrol (RES) influence on the antioxidant defense systems level in the lung and serum of mice is shown in Table
2. The TAS, GSH level and SOD activity of normal groups were significantly higher than those of the EAT control. In the BLM (alone) group, all antioxidant defense systems decreased markedly, compared with the normal and EAT control groups, and applying RES in a dose-dependent way caused an inversion in the BLM-mediated changes of TAS, GSH, and SOD and TOS activities. The RES ${ }_{25}$ and $\mathrm{RES}_{50}$-treated rats had a significantly $(\mathrm{p}<0.05)$ increased SOD, TAS, and GSH level in the lung and the serum compared to the BLM group. The treatment with RES only did not affected the TAS, GSH level, and SOD activity of serum and lung tissues compared with the normal group. However, the treatment with RES only significantly increased the TAS, GSH level, and SOD activity in serum and lung tissues compared with the EAT control group.

The comet assay and 8-OHdG results that indicate the protective effect of RES on the BLM-mediated DNA damage are presented in Table 3. In the BLM group, 8-OHdG levels were observed to be significantly higher when compared with the sham and EAT control groups $(\mathrm{p}<0.05)$. Also, the $8-\mathrm{OHdG}$ levels in $\mathrm{RES}_{25}$ and $\mathrm{RES}_{50}$ treatments can significantly reduce the 8-OHdG levels compared with the EAT control and BLM group. Moreover, RES prevented the BLM-mediated change of 8 -OHdG in a dose-dependent way compared to the BLM group.

The protective effect of RES on mice PBMCs was also investigated using the comet assay. The comet assay was applied to determine the DNA ratio in the tail. The results are presented in Table 3. Only RES treatment showed no genotoxic influence, and the BLM treatment with RES $_{50}$ drastically decreased DNA migration compared to the BLM group $(\mathrm{p}<0.05)$. Taking genotoxicity into consideration, the RES treatment itself did not trigger DNA damage compared to the normal group. There was an important increase in DNA fragmentation in the BLM group when compared to the sham and EAT control groups. The treatment of the animals with RES along with BLM led to a statistically significant decline $(\mathrm{p}<0.05)$ in DNA migration to the tail compared to the sole BLM treatment.

The hidroksiprolin (HPR) was evaluated in lung homogenates. BLM elicited a statistically significant increase in the HPR level lung $(\mathrm{p}<0.05)$ compared with the EAT control group. However, the combination of BLM with $\mathrm{RES}_{50}$ was able to create a significant decrease in the HPR lung levels when compared with the BLM group $(\mathrm{p}<0.05)$ (Table 4). Moreover, the MPO activity was observed to be high in the BLM group. The findings showed that RES treatments decreased the MPO activity which was previously increased due to the BLM use.

The histopathological evaluation of lung tissues taken from the mice in the study is presented in Figure 1. The descriptive statistics and comparison between the groups are shown in Table 4. Fibrosis in the pulmonary samples of the BLM group was observed to be statistically significantly high com- 
Table 1. Effect of resveratrol on the oxidant status of BLM-Induced EAT-Bearing Mice

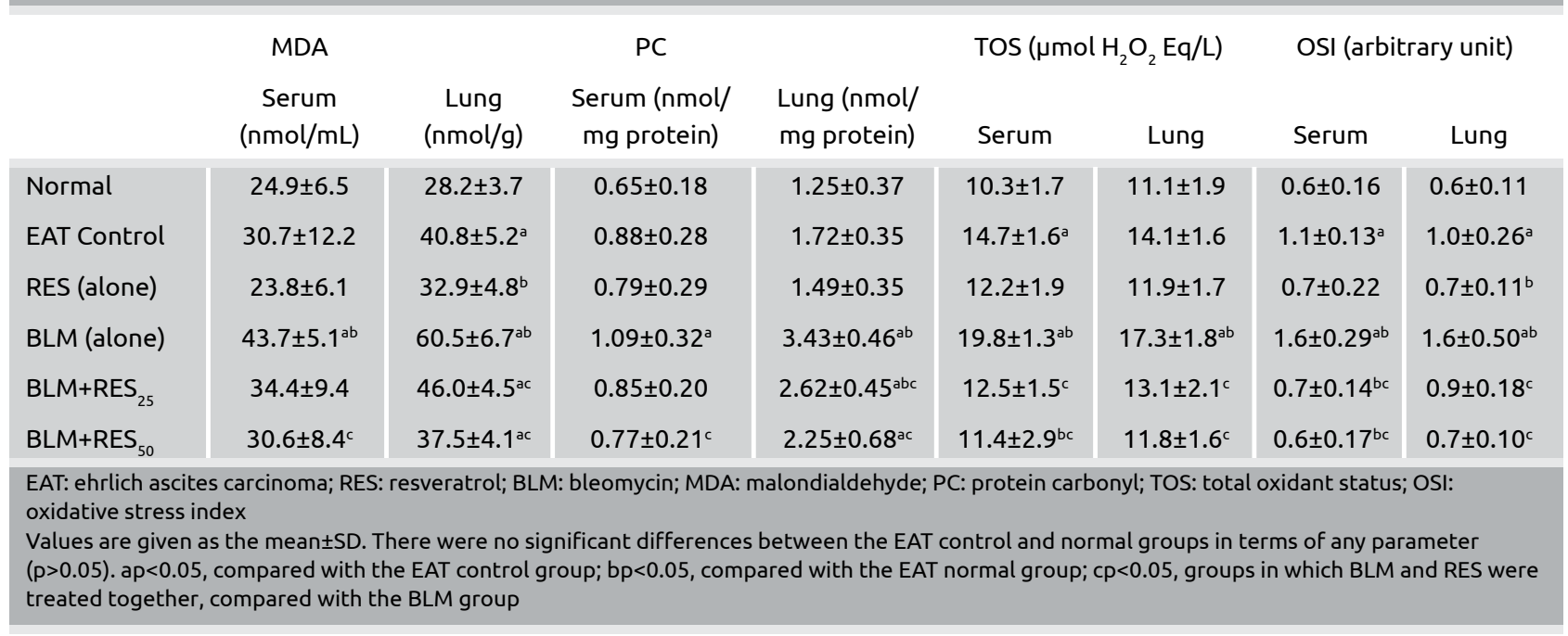

Table 2. Effect of Resveratrol on the Antioxidant Status of BLM-Induced EAT-Bearing Mice

\begin{tabular}{|c|c|c|c|c|c|c|}
\hline & \multicolumn{2}{|c|}{ TAS ( $\mu$ mol Trolox Eq/L) } & \multirow{2}{*}{$\begin{array}{c}\text { GSH } \\
\text { Serum (nmol/mL) }\end{array}$} & \multicolumn{3}{|c|}{ SOD } \\
\hline & Serum & Lung & & Lung (nmol/g) & Serum (U/g) & Lung (U/g) \\
\hline Normal & $1.7 \pm 0.28$ & $1.8 \pm 0.19$ & $7.83 \pm 1.51$ & $3.29 \pm 0.73$ & $93.8 \pm 19.5$ & $160.5 \pm 19.3$ \\
\hline EAT Control & $1.4 \pm 0.14$ & $1.4 \pm 0.23^{\mathrm{a}}$ & $6.39 \pm 0.64^{\mathrm{a}}$ & $2.20 \pm 0.78^{\mathrm{a}}$ & $75.1 \pm 13.4^{\mathrm{a}}$ & $108.6 \pm 22.4^{a}$ \\
\hline RES (alone) & $1.8 \pm 0.40^{\mathrm{b}}$ & $1.8 \pm 0.21^{\mathrm{b}}$ & $7.19 \pm 0.62$ & $2.62 \pm 0.66$ & $65.5 \pm 18.8$ & $137.2 \pm 29.4$ \\
\hline BLM (alone) & $1.3 \pm 0.23^{a}$ & $1.2 \pm 0.30^{\mathrm{ab}}$ & $4.25 \pm 0.75^{\mathrm{ab}}$ & $1.53 \pm 0.37^{\mathrm{a}}$ & $38.7 \pm 11.1^{\mathrm{ab}}$ & $80.1 \pm 20.6^{a}$ \\
\hline BLM+RES25 & $1.8 \pm 0.17^{\mathrm{bc}}$ & $1.5 \pm 0.17^{\mathrm{ac}}$ & $6.10 \pm 1.07^{a c}$ & $2.06 \pm 0.34^{\mathrm{a}}$ & $51.4 \pm 9.3^{\mathrm{ab}}$ & $114.4 \pm 27.5^{c}$ \\
\hline$B L M+R E S 50$ & $1.9 \pm 0.24^{\mathrm{bc}}$ & $1.6 \pm 0.11^{c}$ & $6.57 \pm 1.03^{c}$ & $2.38 \pm 0.27^{a c}$ & $59.8 \pm 13.6^{a c}$ & $148.6 \pm 30.3^{a c}$ \\
\hline
\end{tabular}

Table 3. Effect of resveratrol on DNA damage of BLMInduced EAT-Bearing Mice

8-OHdG (ng/mL)

\begin{tabular}{|l|c|c|c|} 
& Serum & Lung & PBMC \\
\hline Normal & $195.3 \pm 34.1$ & $347.1 \pm 106.2$ & $6.60 \pm 1.7$ \\
\hline EAT Control & $292.9 \pm 52.5$ & $538.0 \pm 66.1^{\mathrm{a}}$ & $13.50 \pm 3.0^{\mathrm{a}}$ \\
\hline RES (alone) & $246.3 \pm 90.7$ & $456.8 \pm 88.1$ & $10.40 \pm 4.0$ \\
\hline BLM (alone) & $630.2 \pm 108.9^{\mathrm{ab}}$ & $1314.7 \pm 142.5^{\mathrm{ab}}$ & $35.30 \pm 6.4^{\mathrm{ab}}$ \\
\hline BLM+RES25 & $435.6 \pm 90.2^{\mathrm{abc}}$ & $889.4 \pm 180.6^{\mathrm{abc}}$ & $21.13 \pm 4.1^{\mathrm{ab}}$ \\
\hline BLM+RES50 & $348.8 \pm 69.3^{\mathrm{ac}}$ & $727.1 \pm 180.1^{\mathrm{ac}}$ & $17.67 \pm 5.4^{\mathrm{ac}}$
\end{tabular}

EAT: ehrlich ascites carcinoma; RES: resveratrol; BLM: bleomycin, 8-OHdG:8-hydroxy-2' -deoxyguanosine; COMET: comet assay; PBMC: peripheral blood mononuclear cell

Values are given as the mean \pm SD. There were no significant differences between the EAT control and normal groups in terms of any parameter ( $p>0.05$ ). ap $<0.05$, compared with the EAT control group; bp $<0.05$, compared with the EAT normal group; $c p<0.05$, groups in which BLM and RES were treated together, compared with the BLM group
Table 4. Grades of lung fibrosis, lung hydroxyproline, and MPO contents

\begin{tabular}{|c|c|c|c|}
\hline & $\begin{array}{l}\text { Hydroxyproline } \\
(\mu \mathrm{g} / \mathrm{mL})\end{array}$ & $\begin{array}{l}\text { MPO } \\
(\mathrm{U} / \mathrm{g})\end{array}$ & $\begin{array}{l}\text { Grade of } \\
\text { fibrosis }\end{array}$ \\
\hline Normal & $163.7 \pm 34.6$ & $6.29 \pm 1.79$ & $0.36 \pm 0.09$ \\
\hline EAT Control & $220.6 \pm 64.8$ & $11.48 \pm 1.46$ & $0.49 \pm 0.13$ \\
\hline RES (alone) & $171.8 \pm 24.0$ & $6.77 \pm 1.87$ & $0.41 \pm 0.11$ \\
\hline BLM (alone) & $315.6 \pm 67.9^{a b}$ & $19.63 \pm 2.21^{\mathrm{ab}}$ & $1.65 \pm 0.40^{\mathrm{ab}}$ \\
\hline$B L M+R S_{25}$ & $251.8 \pm 85.0^{a}$ & $14.64 \pm 2.43^{\mathrm{abc}}$ & $0.85 \pm 0.27^{\mathrm{abc}}$ \\
\hline $\mathrm{BLM}+\mathrm{RES}_{50}$ & $197.1 \pm 37.5^{c}$ & $10.87 \pm 2.34^{c}$ & $0.68 \pm 0.22^{\mathrm{ac}}$ \\
\hline \multicolumn{4}{|c|}{$\begin{array}{l}\text { EAT: ehrlich ascites carcinoma; RES: resveratrol; BLM: bleomycin; } \\
\text { MPO: myeloperoxidase } \\
\text { Values are given as the mean } \pm \text { SD. There were no significant } \\
\text { differences between the EAT control and normal groups in terms } \\
\text { of any parameter }(P>0.05) \text {. aP }<0.05 \text {, compared with the EAT control } \\
\text { group; bP }<0.05 \text {, compared with the EAT normal group; } C P<0.05 \text {, } \\
\text { groups in which BLM and RES were treated together, compared with } \\
\text { the BLM group }\end{array}$} \\
\hline
\end{tabular}


Table 5. Effect of resveratrol on serum liver enzymes and renal function markers of BLM-Induced EAT-Bearing Mice

\begin{tabular}{|c|c|c|c|c|c|}
\hline & BUN (mg/dL) & CRE (mg/dL) & AST (U/L) & ALT (U/L) & $\mathrm{LDH}(\mathrm{U} / \mathrm{L})$ \\
\hline Normal & $15.8 \pm 3.8$ & $0.2 \pm 0$ & $39.6 \pm 3.2$ & $26.2 \pm 7.9$ & $1.7 \pm 0.3$ \\
\hline EAT Control & $19.6 \pm 3.8$ & $0.2 \pm 0.1$ & $40.8 \pm 6.1$ & $30.2 \pm 9.1$ & $1.9 \pm 0.4$ \\
\hline RES (alone) & $15.9 \pm 3.8$ & $0.2 \pm 0.1$ & $37.2 \pm 5.2$ & $23.9 \pm 2.4$ & $1.6 \pm 0.6$ \\
\hline BLM (alone) & $35.5 \pm 2.2^{\mathrm{ab}}$ & $0.4 \pm 0.1^{\mathrm{ab}}$ & $70.9 \pm 13.1^{\mathrm{ab}}$ & $52.2 \pm 7.1^{\mathrm{ab}}$ & $3.5 \pm 1^{\mathrm{ab}}$ \\
\hline$B L M+R S_{25}$ & $20.8 \pm 3^{a c}$ & $0.2 \pm 0.1^{c}$ & $44.2 \pm 12.5^{c}$ & $39.7 \pm 7.3^{a c}$ & $2.4 \pm 0.3^{c}$ \\
\hline$B L M+R S_{50}$ & $18.7 \pm 3^{c}$ & $0.2 \pm 0.1^{c}$ & $41.6 \pm 7.4^{c}$ & $32.5 \pm 7.2^{c}$ & $2.2 \pm 0.4^{c}$ \\
\hline \multicolumn{6}{|c|}{$\begin{array}{l}\text { EAT: ehrlich ascites carcinoma; RES: resveratrol; BLM: bleomycin; BUN: blood urea nitrogen; CRE: creatinine; AST: aspartate transaminase; ALT: alanine } \\
\text { transaminase; LDH: lactate dehydrogenase } \\
\text { Values are given as the mean } \pm \text { SD. There were no significant differences between the EAT control and normal groups in terms of any parameter } \\
\text { (p>0.05). aP<0.05, compared with the EAT control group; bp }<0.05 \text {, compared with the EAT normal group; } c p<0.05 \text {, groups in which BLM and RES were } \\
\text { treated together, compared with the BLM group }\end{array}$} \\
\hline
\end{tabular}

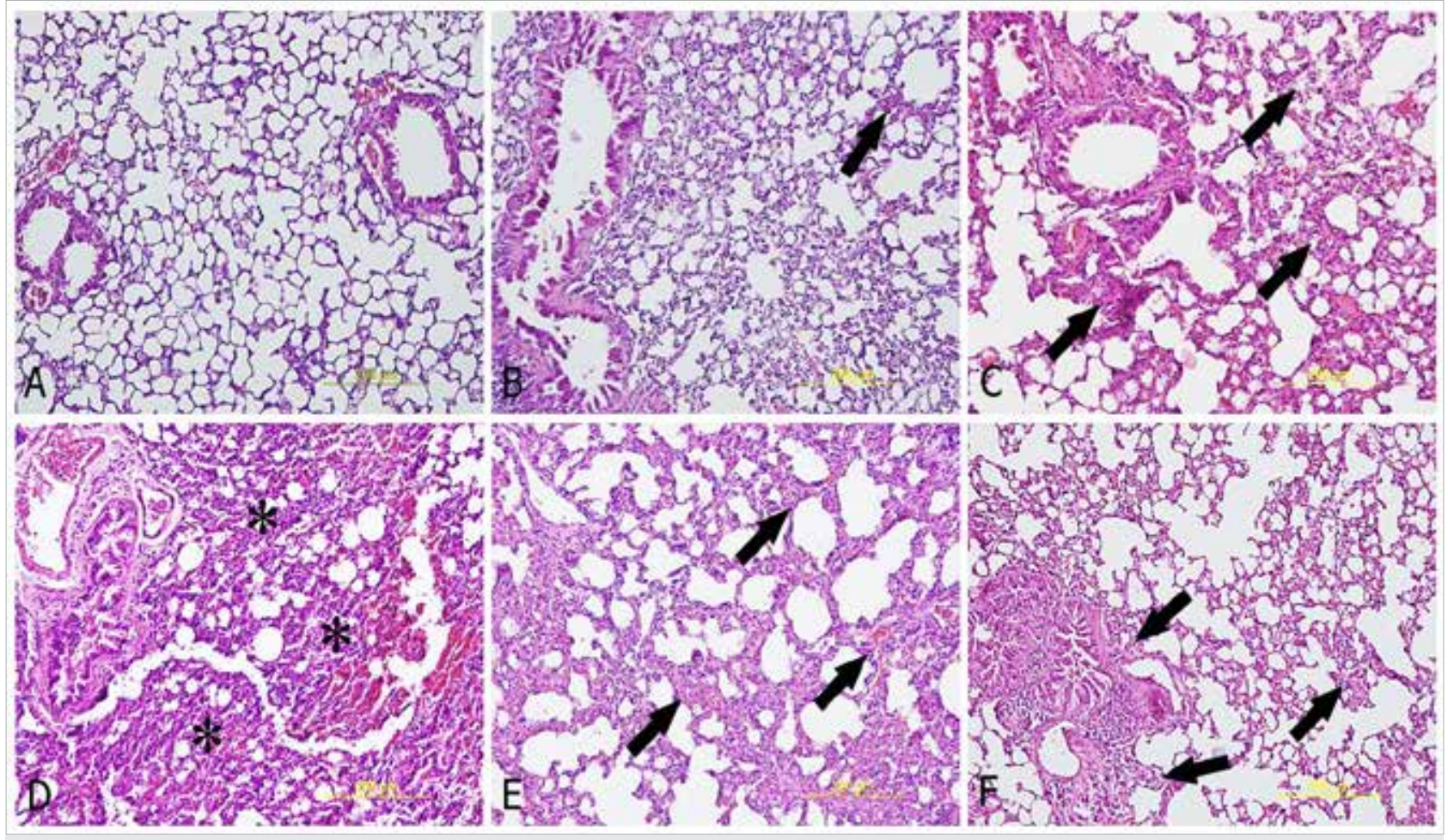

Figure 1. a-f. Histopathological changes in the lung caused by the BLM exposure and its amelioration by the RES treatment (a) The sham group showing normal histology of the lung (H\&E); (b) RES-treated animal's lung shows mild fibrosis (arrows) and normal alveolar architecture that resembles the control (H\&E); (c) an EAT group animal showing mild thickening of alveolar and inflammatory cells (arrows) (H\&E); (d) the BLM group showing severe diversification fibrous and inflammation (stars) (H\&E); (e) lung sections of a BLM+RES-25 group animal show moderate inflammation (arrows) (H\&E); (f) lung sections of a BLM+RES-50 group animal show moderate fibrosis and inflammation (arrows) (H\&E)

pared to the other groups $(\mathrm{p}<0.05)$. An evident reduction in fibrosis was seen in the BLM+RES group, and the level in the RES $_{25}$ group in particular was statistically significantly high compared to the pulmonary tissues of the sham group $(p<0.05)$. A statistically significant reduction in fibrosis was determined in the pulmonary tissues of the RES $_{50}$ group, but no statistically significant difference was determined in the sham group pulmonary tissue $(\mathrm{p}<0.05)$. From the study results, it was determined that RES $(25 \mathrm{mg} / \mathrm{kg}$ and $50 \mathrm{mg} /$ $\mathrm{kg}$ ) partially reversed the cycle of the BLM-induced pulmo- nary fibrosis, evaluated by the increased semi-quantitative fibrosis score, the HPR content, and the MPO activity in the pulmonary tissue.

The serum levels of biochemical parameters are shown in Table 4. Although the levels of liver enzymes (AST, ALT, and LDH) and renal function markers (BUN and CRE) increased significantly between the BLM (alone) and EAT control groups, each dose of RES supplementation in the BLM-treated mice resulted in marked decreases of these biochemical parameters. 


\section{Discussion}

Bleomycin (BLM) is an anticancer drug, widely used in the treatment of different kinds of cancers. However, when BLM molecules interact with oxygen and ions, this leads to an increase in superoxide and other ROS (1). By showing a cytotoxic and genotoxic effect, an increase in the BLM-related ROS production in the pulmonary tissue forms unwanted side effects such as pulmonary fibrosis. Therefore, the protective effects of a series of antioxidant substances have been researched to provide protection against BLM toxicity (2-8, $10,11)$.

In this study, for the first time, to the best of our knowledge, an examination of the protective effect of RES on lung histopathology and oxidant parameters such as DNA damage (comet assay and 8-OHdG), MDA, MPO, PC, TOS, and OSI, which increased related to BLM in the serum and pulmonary tissue of mice carrying EAT, was conducted. In addition, the potential role of RES was investigated in the prevention of BLM-related pulmonary toxicity and genotoxicity, such as the increase in SOD, TAS, and GSH in the antioxidant defense system. The results of the study showed that RES reduced the level of MDA, PC, TOS, OSI, HPR, and DNA damage, which shows an increase related to BLM, and corrected the decline in the antioxidant system related to BLM in the serum and pulmonary tissue of mice.

In studies by Akgedik et al. (13) and Sener et al. (25), similar to the current study, it was determined that RES administered after BLM prevented pulmonary fibrosis to a significant degree in experimental rats, and this effect was due to antioxidant and anti-inflammatory properties. It was also shown that RES lowered the MDA level in serum and pulmonary tissue and increased the reduction in the TAS level in pulmonary tissue related to the BLM exposure in rats. The depletion of the TAS level in the serum and pulmonary tissue and the reverse effect of the increase in the MDA level in the pulmonary tissue could be due to the possible RES antioxidant activity (20).

By leading to an increase in the free radical production, BLM causes single or double chain breakages in DNA (37-39). Furthermore, the damage seen in the pulmonary tissue after BLM treatment, which results in increased ROS and RNS production in active inflammatory cells further increases DNA damage $(3,40)$. In a study by Yasmina et al. (41), the chemotherapeutic agent BLM showed a cytotoxic and genotoxic effect on isolated rat lymphocytes, and bee toxin that was administered as protection reduced the level of the BLMrelated DNA damage.

In the current study, the level of DNA damage caused by BLM in the serum and pulmonary tissue was determined with 8-OHdG, and the level of damage in the PBMC cells was determined with the comet assay. The biomarker, $8-\mathrm{OHdG}$, released secondary to DNA damage, is regarded as the most significant indicator of DNA damage (42). Hydroxyl radicals eliminate hydrogen from nucleic acids or react with double bonds, leading to 8-OHdG (43). Yasmina et al. and Tayebeh et al. $(40,41)$ suggested that DNA damage is increased by following BLM in rat PBMC and sperm. Our results showed that the 8-OHdG score is also a good indicator of tissue damage in the BLM-induced genotoxicity in experimental mice. The results of the study showed that RES at doses of 25 and $50 \mathrm{mg} / \mathrm{kg}$ effectively protected against the DNA damage stimulated by the BLM treatment in mice carrying EAT.

Previous studies have suggested that the DNA damage was decreased by antioxidant supplementation $(44,45)$, and the results of the present study supported these data. RES exerted its antioxidant effects by reducing the ROS-mediated 8-OHdG levels, which indicates the prevention of oxidative DNA damages. This finding was the most important restorative effect of RES treatment. The protective effect of RES on the PBMCs of mouse, which DNA damage was overt due to the BLM induction, was studied using the comet assay. Findings of the comet assay demonstrated enhancements in the amount of DNA damage in the BLM administrated PBMCs. Treatment with BLM substantially diminished the BLM-induced DNA damage in the comet assay. These results strongly demonstrate that RES possesses genoprotective efficiency.

Oxidative stress disrupts the equilibrium between the production and elimination of oxidants. This can be due to an extreme level of oxidants produced in the body or weak antioxidant defense mechanisms that is mostly seen at chemotherapy regimens, especially with BLM treatments. In this respect, the present study assessed the overall effects of the use of BLM on oxidative and antioxidative status via different perspectives. OSI reveals the redox equilibrium among oxidation and antioxidation, and it has been used as the major indicator for the body redox balance. Separate evaluation of various oxidant molecules such as superoxide radical, hydroxyl radical, and hydrogen peroxide $\left(\mathrm{H}_{2} \mathrm{O}_{2}\right)$ is not practical; however, their oxidant impacts are incremental. Thus, we measured TOS in the lung tissue and the serum in accordance with the previous descriptions by Erel (32). Likewise, rather than individually determining antioxidant molecules, we measured TAS, according to the techniques by Erel, as well (33). In previous studies, it was suggested that OSI could show the oxidative state more precisely than the sole levels of TOS or TAS (46). Hence, OSI could be regarded as an approximate indicator for identifying the BLM-mediated genotoxicity, lung toxicity, and preservation provided by RES in subjects undergoing BLM treatment. In the BLM administrated group, the levels of TOS and OSI were dramatically enhanced compared with the sham, ETA control, and sole-RES administrated groups, whereas TAS levels were clearly reduced when compared to the control group. However, applying RES with BLM decreased the levels of TOS and OSI, while it enhanced TAS levels when compared with the BLM group. These results demonstrate that the exposure to BLM caused an increase in 
oxidative stress in the tissues, and elevated oxidative stress was hampered by the RES treatment.

Myeloperoxidase (MPO) is a pro-oxidant enzyme widely used as a neutrophil infiltration index. An increase in the MPO secretion, which is an enzyme that reacts with $\mathrm{H}_{2} \mathrm{O}_{2}$, from the increased active neutrophils in the lungs following the application of BLM, leads to ROS formation causing damage in the lungs $(2,4)$. In the current study, the evident increase in the MPO activity in the lungs of the BLM group suggests that neutrophil activation plays a critical role in the harmful effect of BLM. In a study conducted on rats by Kilic et al. (4), a similar high level of the MPO activity in the lungs was observed following the BLM treatment. An increase in the MPO activity was determined to have been prevented in both the BLM+RES groups compared to the BLM group. The role of RES in weakening lung MPO activity has been shown to be related to the capability of the preventative effect of reducing neutrophil infiltration (25).

Lipid peroxidation through ROS causes the loss of membrane stability and integrity, leading to increased transepithelial permeability and fibrosis in the lungs (47). MDA is a reactive carbon component used as a marker of lipid peroxidization (48). Consistent with the findings of previous studies, an increase was observed in the MDA levels in the serum and pulmonary tissue of mice given BLM (49). The application of RES significantly reduced the BLM-induced oxidative stress, as can be understood from the low MDA levels. This protective effect of RES is thought to be related to the effect of sweeping free radicals and antioxidant activity.

From the interaction of ROS and proteins, PC products occur as a result of damage occurring in many amino acid remnants and/or the peptide backbone. Protein carbonyls are the most widely measured product of protein oxidization. The determination of PC levels is a sensitive method in the identification of oxidative protein damage (50). High PC content of the BLM group may originate from an increase in free radicals as a result of the BLM toxicity, because while BLM increases the amount of ROS, it also decreases the antioxidant production. The application of RES, with its sweeping of free radicals, may block the inducing effect of BLM on protein oxidation and the reduced lipid and TOS level caused by BLM.

Superoxide dismutase (SOD) is one of the antioxidant endogenous enzymes that plays an important role in the cellular antioxidant system against oxidative damage by transforming superoxide radicals to $\mathrm{H}_{2} \mathrm{O}_{2}(51)$. By entering into molecular interaction with oxygen and iron, BLM produces a superoxide anion and other oxygen metabolites $(38,39)$. A decrease in the SOD activity that will neutralize these radicals leads to a genotoxic and cytotoxic effect seen in PBMC and the lungs by other ROS molecules, primarily hydroxyl radical associated with an increase of superoxide radicals. Increasing damage in the lungs in particular causes fibrosis.
Glutathione (GSH) is an important antioxidant molecule, which is a non-protein thiol, and by directly reacting with $\mathrm{O}_{2}$, peroxyl roots, and singlet oxygen, the thiol in proteins and other neutrophylic groups protects against the toxic effects of ROS. The intracellular GSH concentration is an important marker of the degree of the BLM-related pulmonary damage (51). It has been shown that the cellular GSH concentration could be affected by the exogenous application of antioxidants (47-52). In a study by Sener et al. (25), the depletion of GSH reserves following the administration of BLM was corrected with the RES treatment.

In the current study, a significant increase in the GSH level and SOD activity was found only in the RES group. In comparison with the EAT control group, the SOD and GSH levels of the BLM group were significantly reduced. Both dosage levels of RES and all the doses of combined treatment of BLM significantly increased the GSH content and SOD activity. Excessive ROS production and SOD and GSH depletion in toxicity caused by BLM has been shown in previous studies (53). Therefore, the GSH depletion and decrease in the SOD activity may have caused the increase in lipid and protein oxidization in the BLM group. Thus, the modulation of GSH metabolism with resveratrol may be considered a useful adjuvant therapy in the BLM treatment.

Liver and kidney damage do not always show increases in BUN and CRE levels in addition to serum AST, ALT, and $\mathrm{LDH}$ activities. These increases may originate from other causes, such as muscle trauma and stress (53). However, in the current study, an increase in the above-mentioned parameters was most likely from the BLM application. As seen in Table 1, although the AST, ALT, LDH, BUN, and CRE levels were increased in the BLM group compared to the EAT control group, the levels were significantly reduced with the support of each RES dose. In some previous studies, increased serum liver enzymes have been associated with increasing ROS (26).

The results obtained in the study were supported by the histopathological evaluation. Consistent with the findings of previous studies, the HPR level was determined to be high in the BLM group of the current study, and there was a high level of damage in the Ashcroft scoring of the histological findings. There are several studies showing that several antioxidant agents play a protective role in pulmonary fibrosis caused by BLM (2-7). In these studies, it has been determined that according to the semi-quantitative histopathological evaluation and the lung HPR content, antioxidant substances generally prevented or reduced pulmonary fibrosis induced by BLM in rats. Similarly, in the current study, RES was determined to have reduced pulmonary fibrosis.

In this study, the treatment of mice with EAT, which included $25 \mathrm{mg} / \mathrm{kg}$ and $50 \mathrm{mg} / \mathrm{kg}$ doses of RES, was seen to be effectively protective against pulmonary fibrosis stimulated with BLM. These results are in accordance with previous research of the protective role of RES against pulmonary damage (25, 
26). All the RES doses played an antioxidant role against the application of BLM in the mice with EAT (Table 2). In the groups where BLM and RES were applied together, there was a significant reduction in the serum and pulmonary tissue TOS, MDA, PC, MPO, and HPR concentrations. In both the RES+BLM groups, the TOS, MDA, PC, MPO, and HPR levels were reduced almost to the level of the EAT control group.

The high TOS, MDA, and PC content of the BLM-only group could have originated from an increase in free radicals as a result of the BLM toxicity, because while BLM increases the amount of ROS, it also reduces antioxidant production. The application of RES, with its sweeping of free radicals, may block the inducing effect of BLM on protein oxidation and the reduced lipid and TOS level caused by BLM. Similar reducing effects of RES on LPO have been previously reported $(19,25,26)$.

\section{Conclusion}

The results of this study showed that the DNA damage and the fibrosis formed as a result of lipid and protein oxidization caused by BLM in mice with EAT could be reduced with the application of resveratrol. This protective effect of RES can be explained by the strong antioxidant effect eliminating or preventing the formation of free oxygen radicals. RES can therefore be considered as a potential therapeutic agent that could be used in the treatment of pulmonary fibrosis, DNA damage in the lungs, and genotoxicity.

Ethics Committee Approval: Ethics committee approval was received for this study from the ethics committee of Bezmialem Vakif University $(2016 / 66)$.

Peer review: Externally peer reviewed.

Conflict of Interest: The authors have no conflicts of interest to declare.

Financial Disclosure: The authors declare that this study has received no financial support.

Etik Komite Onayı: Bu çalışma için etik komite onayı Bezmialem Vakıf Üniversitesi'nden (2016/66) alınmıştır.

Hakem Değerlendirmesi: Dış bağımsız.

Çıkar Çatışması: Yazarlar çıkar çatışması bildirmemişlerdir.

Finansal Destek: Yazarlar bu çalışma için finansal destek almadıklarını beyan etmişlerdir.

\section{References}

1. Kilic T, Ciftci O, Cetin A, Kahraman H. Preventive effect of chrysin on bleomycin-induced lung fibrosis in rats. Inflammation 2014;37: 2116-24. [CrossRef]
2. Schroll S, Lange TJ, Arzt M, Sebah D, Nowrotek A, Lehmann $\mathrm{H}$, et al. Effects of simvastatin on pulmonary fibrosis, pulmonary hypertension and exercise capacity in bleomycin-treated rats. Acta Physiol (Oxf) 2013; 208: 191-201. [CrossRef]

3. Della Latta V, Cecchettini A, Del Ry S, Morales MA. Bleomycin in the setting of lung fibrosis induction: From biological mechanisms to counteractions. Pharmacol Res 2015; 97: 12230. [CrossRef]

4. Kilic T, Parlakpinar H, Polat A, Taslidere E, Vardi N, Sarihan E, et al. Protective and therapeutic effect of molsidomine on bleomycin-induced lung fibrosis in rats. Inflammation 2014; 37: 1167-78. 5. Zhu B, Ma AQ, Yang L, Dang XM. Atorvastatin attenuates bleomycin-induced pulmonary fibrosis via suppressing iNOS expression and the CTGF (CCN2)/ERK signaling pathway. Int J Mol Sci 2013; 14(: 24476-91.

5. Zhu B, Ma AQ, Yang L, Dang XM. Atorvastatin attenuates bleomycin-induced pulmonary fibrosis via suppressing iNOS expression and the CTGF (CCN2)/ERK signaling pathway. Int J Mol Sci 2013; 16: 14: 24476-91. [CrossRef]

6. Sausville E, Peisach, J, Horwitz SB. Effect of chelating agents and metal ions on the degradation of DNA by bleomycin. Biochemistry 1978; 17: 2740-6. [CrossRef]

7. Zitnik R, Respir J. Drug-induced lung disease: cancer chemotherapy agents 1995; 16: 855-65.

8. Reinert T. Bleomycin-Induced Lung Injury. Hindawi Publishing Corporation Journal of Cancer Research 2013.

9. Levine RL, Garland D, Oliver CN, Amici A, Climent I, Lenz AG, et al. Determination of carbonyl content in oxidatively modified proteins. Methods Enzymol 1990; 186: 464-78. [CrossRef]

10. Verma R, Kushwah L, Gohel D, Patel M, Marvania T, Balakrishnan S. Evaluating the Ameliorative Potential of Quercetin against the Bleomycin-Induced Pulmonary Fibrosis in Wistar Rats. Pulm Med 2013; DOI: 10.1155/2013/921724. [CrossRef]

11. Chitra P, Saiprasad G, Manikandan R, Sudhandiran G. Berberine attenuates bleomycin induced pulmonary toxicity and fibrosis via suppressing NF-kappaB dependant TGF-beta activation: a biphasic experimental study. Toxicol Lett 2013; 219: 178-93. [CrossRef]

12. Covvey JR, Mancl EE. Recent evidence for pharmacological treatment of idiopathic pulmonary fibrosis. Ann Pharmacother 2014; 48: 1611-9. [CrossRef]

13. Akgedik R, Akgedik Ş, Karamanlı H, Uysal S, Bozkurt B, Ozol D, et al. Effect of resveratrol on treatment of bleomycininduced pulmonary fibrosis in rats. Inflammation 2012; 35 : 1732-41. [CrossRef]

14. Iraz M, Erdogan H, Kotuk M, Yagmurca M, Kilic T, Ermis H, et al. Ginkgo biloba inhibits bleomycin-induced lung fibrosis in rats. Pharmacol Res 2006; 53: 310-6. [CrossRef]

15. Yildirim Z, Kotuk M, Erdogan H, Iraz M, Yagmurca M, Kuku I, et al. Preventive effect of melatonin on bleomycin-induced lung fibrosis in rats. J Pineal Res 2006; 40: 27-33. [CrossRef]

16. Ermis H, Parlakpinar H, Gulbas G, Vardi N, Polat A, Cetin A, et al. Protective effect of dexpanthenol on bleomycin-induced pulmonary fibrosis in rats. Naunyn Schmiedebergs Arch Pharmacol 2013; 386: 1103-10. [CrossRef]

17. Moeller A, Ask K, Warburton D, Gauldie J, Kolb M. The bleomycin animal model: a useful tool to investigate treatment options for idiopathic pulmonary fibrosis? Int J Biochem Cell Biol 2008; 40: 362-82. [CrossRef] 
18. Signorelli P, Ghidoni R. Resveratrol as an anticancer nutrient: molecular basis, open questions and promises. J Nutr Biochem 2005; 16: 449-66. [CrossRef]

19. Athar M, Back JH, Tang X, Kim KH, Kopelovich L, Bickers DR, et al. Resveratrol: a review of preclinical studies for human cancer prevention. Toxicol Appl Pharmacol 2007; 224: 274-83. [CrossRef]

20. Wood LG, Wark PA, Garg ML. Antioxidant and anti-inflammatory effects of resveratrol in airway disease. Antioxid Redox Signal 2010; 13: 1535-48. [CrossRef]

21. Bradamante S, Barenghi L, Villa A. Cardiovascular protective effects of resveratrol. Cardiovasc Drug Rev 2004; 22: 169-88. [CrossRef]

22. Wolter F, Ulrich S, Stein J. Molecular mechanisms of the chemopreventive effects of resveratrol and its analogs in colorectal cancer: key role of polyamines? J Nutr 2004; 134: 3219-22. [CrossRef]

23. de la Lastra CA, Villegas I. Resveratrol as an antioxidant and pro-oxidant agent: mechanisms and clinical implications. Biochem Soc Trans 2007; 35: 1156-60. [CrossRef]

24. Akgedik R, Akgedik S, Karamanli H, Uysal S, Bozkurt B, Ozol D, et al. Effect of resveratrol on treatment of bleomycininduced pulmonary fibrosis in rats. Inflammation 2012; 35: 1732-41. [CrossRef]

25. Sener G, Topaloglu N, Sehirli AO, Ercan F, Gedik N. Resveratrol alleviates bleomycin-induced lung injury in rats. Pulm Pharmacol Ther 2007; 20: 642-9. [CrossRef]

26. Özkol H, Musa D, Tuluce Y, Koyuncu I. Ameliorative influence of Urtica dioica $\mathrm{L}$ against cisplatin-induced toxicity in mice bearing Ehrlich ascites carcinoma. Drug Chem Toxicol 2012; 35: 251-7. [CrossRef]

27. Bradley PP, Priebat DA, Christensen RD, Rothstein G. Measurement of cutaneous inflammation: estimation of neutrophil content with an enzyme marker. J Invest Dermatol 1982; 78: 206-9. [CrossRef]

28. Kandar R, Hajkova N. Assay of total glutathione and glutathione disulphide in seminal plasma of male partners of couples presenting for a fertility evaluation. Andrologia 2014; 46 :1079-88. [CrossRef]

29. Ohkawa H, Ohishi N, Yagi K. Assay for lipid peroxides in animal tissues by thiobarbituric acid reaction. Anal Biochem 1979; 95: 351-8. [CrossRef]

30. Lowry OH, Rosebrough NJ, Farr AL, Randall RJ. Protein measurement with the Folin phenol reagent. J Biol Chem 1951; 193: 265-75.

31. McCord J, Fridovich I. Superoxide dismutase, an enzymatic function for erythrocuprein (hemocuprein). J Biol Chem 1969; 244: 6049-53.

32. Erel O. A new automated colorimetric method for measuring total oxidant status. Clin Biochem 2005; 38: 1103-11. [CrossRef]

33. Erel O. A novel automated direct measurement method for total antioxidant capacity using a new generation, more stable ABTS radical cation. Clin Biochem 2004; 37: 277-85. [CrossRef]

34. Harma $\mathrm{M}^{1}$, Harma $M$, Erel O. Increased oxidative stress in patients with hydatidiform mole. Swiss Med Wkly 2003; 133: 563-6.

35. Kocyigit A, Koyuncu I, Taskin A, Dikilitas M, Bahadori F, Turkkan B. Antigenotoxic and antioxidant potentials of newly derivatized compound naringenin-oxime relative to naringenin on human mononuclear cells. Drug Chem Toxicol 2016; 39: 66-73 [CrossRef]
36. Ashcroft T, Simpson JM, Timbrell V. Simple method of estimating severity of pulmonary fibrosis on a numerical scale. J Clin Pathol 1988; 41: 467-70. [CrossRef]

37. Vig B, Lewis R. Genetic toxicology of bleomycin. Mutat Res 1978; 55: 121-45. [CrossRef]

38. Povirk L, Austin M. Genotoxicity of bleomycin. Mutat Res 1991; 257: 127-43. [CrossRef]

39. Lim LO, Neims AH. Mitochondrial DNA damage by bleomycin. Biochem Pharmacol 1987; 36: 2769-974. [CrossRef]

40. Amirshahi T, Najafi G, Nejati V. Protective effect of royal jelly on fertility and biochemical parameters in bleomycin-induced male rats. Iran J Reprod Med 2014; 12: 209-16.

41. Yasmina M. Abd-Elhakim, Samah R. Khalil, Awad A, Al-Ayadhi LY. Combined Cytogenotoxic Effects of Bee Venom and Bleomycin on Rat Lymphocytes: An In Vitro Study. Biomed Res Int 2014; DOI: 10.1155/2014/173903 [CrossRef]

42. Stepniak J, Karbownik-Lewinska M. 17ß-estradiol prevents experimentally-induced oxidative damage to membrane lipids and nuclear DNA in porcine ovary. Syst Biol Reprod Med 2016; 62: 17-21. [CrossRef]

43. Cadet J. Oxidative degradation pathways of cellular DNA: product formation and mechanistic insights. Free Radic Biol Med 2014; DOI: 10.1016/j.freeradbiomed.2014.10.598. [CrossRef]

44. Abraham SK, Khandelwal N, Hintzsche H, Stopper H. Antigenotoxic effects of resveratrol: assessment of in vitro and in vivo response. Mutagenesis 2016; 31: 27-33.

45. Bingöl G, Gülkaç MD, Dillioğlugil MO, Polat F, Kanli AÖ. Effect of resveratrol on chromosomal aberrations induced by doxorubicin in rat bone marrow cells. Mutat Res Genet Toxicol Environ Mutagen 2014; 766: 1-4. [CrossRef]

46. Karafakıoğlu YS, Bozkurt MF, Hazman O, Fidan AF. Efficacy of safranal to cisplatin-induced nephrotoxicity. Biochem J 2017; 474: 1195-203 [CrossRef]

47. Venkatesan N, Punithavathi V, Chandrakasan G. Curcumin protects bleomycin-induced lung injury in rats. Life Sci 1997; 61: PL51-8. [CrossRef]

48. Lei Y, Wang K, Deng L, Chen Y, Nice EC, Huang C. Redox regulation of inflammation: old elements, a new story. Med Res Rev; 35: 306-40. [CrossRef]

49. Zhao L, Wang X, Chang Q, Xu J, Huang Y, Guo Q, et al. Neferine, a bisbenzylisoquinline alkaloid attenuates bleomycin-induced pulmonary fibrosis. Eur J Pharmacol; 627: 304-12. [CrossRef]

50. Evans P, Lyras L, Halliwell B. Measurement of protein carbonyls in human brain tissue. Methods Enzymol 1999; 300: 14556. [CrossRef]

51. Lushchak VI. Glutathione homeostasis and functions: potential targets for medical interventions. J Amino Acids 2012; DOI: 10.1155/2012/736837 [CrossRef]

52. Cortijo J, Cerda-Nicolas M, Serrano A, Bioque G, Estrela JM, Santangelo F, et al. Attenuation by oral $\mathrm{N}$-acetylcysteine of bleomycin-induced lung injury in rats. Eur Respir J 2001;17: 1228-35. [CrossRef]

53. Hemmati AA, Rezaie A, Darabpour P. Preventive effects of pomegranate seed extract on bleomycin-induced pulmonary fibrosis in rat. Jundishapur J Nat Pharm Prod 2013; 8: 76-80. [CrossRef] 